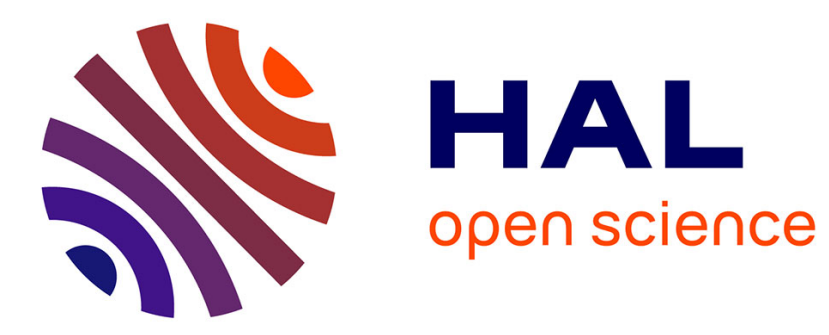

\title{
Clitic Clusters
}

\author{
Diego Pescarini
}

\section{To cite this version:}

Diego Pescarini. Clitic Clusters. The Wiley Blackwell Companion to Syntax (Second Edition), John Wiley \& Sons, Inc., 2017, 10.1002/9781118358733.wbsyncom018 . hal-03576099

\section{HAL Id: hal-03576099 \\ https://hal.science/hal-03576099}

Submitted on 15 Feb 2022

HAL is a multi-disciplinary open access archive for the deposit and dissemination of scientific research documents, whether they are published or not. The documents may come from teaching and research institutions in France or abroad, or from public or private research centers.
L'archive ouverte pluridisciplinaire HAL, est destinée au dépôt et à la diffusion de documents scientifiques de niveau recherche, publiés ou non, émanant des établissements d'enseignement et de recherche français ou étrangers, des laboratoires publics ou privés. 


\title{
Clitic Clusters
}

\author{
Diego Pescarini
}

\begin{abstract}
Romance clitic combinations. It summarizes some data and treatments of clitic sequences, focusing on three aspects: combinatorial restrictions, orderings, and morphological irregularities.

First, not all clitic combinations are allowed, as combinatorial gaps arise from both robust cross-linguistic restrictions (the Person Case Constraint, or PCC) and language-specific constraints. The former has received much attention in the recent syntactic literature. Besides the PCC, however, Romance displays various kinds of gaps, part of which are arguably due to an identity-avoidance principle whose morphological or syntactic nature is still under discussion.

Second, the order of clitic elements within a cluster is rigidly set on a language-specific basis and, third, the morphological shape of the cluster does not result from the agglutination of single clitics, as morphological irregularities arise rather frequently. Previous analyses argued that these aspects are due to some sort of extrasyntactic computation, namely morphological templates, post-syntactic operations, output constraints, etc..

Such non-syntactic devices, which do not follow from any general principle of Universal Grammar, are usually postulated to account for language-specific orderings and irregularities. In fact, however, ordering phenomena and morphological irregularities seem to be systematic, with certain patterns recurring frequently across languages. The second part of the chapter aims to show that ordering phenomena and morphological irregularities are related and both may be deemed evidence of the syntactic make-up of clitic sequences. In particular, it is shown that, building on a very restrictive theory of linearization, one may deal with the variation in clitic ordering without postulating extrasyntactic levels of computation.
\end{abstract}

Keywords: clitic; grammar; language; pronouns; Romance languages; syntax

\section{Introduction}

Since Perlmutter (1971), combinations of Romance object clitics have been a major topic in generative grammar as their behavior entails a fine-grained division of labor between different modules of Universal Grammar (UG) (Rezac 2011). In particular, previous studies have been devoted to three main puzzles: (i) combinatorial gaps; (ii) ordering; and (iii) morphological irregularities.

Within the generative framework, much of the literature has focused on restrictions, in particular on the so-called Person Case Constraint (PCC; see Bonet 1991; Anagnostopoulou 2003; 2005; further references are given below). Conversely, ordering phenomena and morphological irregularities have received far less attention, probably because, unlike the PCC, their explanation does not follow directly from core syntactic mechanisms, but rather from interface procedures which have been theorized within the Distributed Morphology approach (Bonet 1991; 1994; 1995; 2008; Harris 1994; 1997). Meanwhile, Manzini and Savoia (2002; 2004; 2005; 2009) have argued for a radically different alternative, based on a strictly lexicalist view wherein no morphological computation is envisaged.

The goal of the present chapter is twofold: on the one hand, it aims to review some data and proposals to illustrate the state of the art in morphosyntactic research on the aforementioned aspects (PCC, order, opacity); on the other, it introduces new data and a tentative speculation on the correlation between ordering and opacity which may open the door to further syntactic research.

The structure of the work is as follows: section 2 summarizes some relevant findings, data, and ideas concerning the morphosyntax of clitic combinations; section 3 deals with the diachronic evolution of Romance clitic sequences; section 4 is an aside on the behavior of clitic clusters in restructuring environments; section 5 focuses on morphological irregularities; section 6 is about a peculiar pattern of doubling; section 7 addresses data from French and French vernaculars; and section 8 concludes. 


\section{Three puzzles regarding clitic combinations}

\subsection{Combinatorial restrictions}

Not all clitic combinations are possible. The best-known restriction is the so-called Person Case Constraint (PCC), which in (almost) all the Romance languages prevents combinations containing a first- or second-person (1/2p) accusative clitic, in particular in co-occurrence with a third-person (3p) dative clitic:

(1) French

a. *Philippe te leur a présenté hier. Philippe you $=$ to.them $=$ has introduced yesterday

'Philippe introduced you to them yesterday.'

Italian

b. *Filippo gli ti ha presentato ieri.

Filippo to.him $=$ you $=$ has introduced yesterday

'Filippo introduced you to him yesterday.'

In the last decades, a vast literature has focused on PCC and PCC-like restrictions in Romance (Postal 1990; Bonet 1991; Gerlach 1998; Anagnostopoulou 2005; Bianchi 2006; Nevins 2007; Ormazabal and Romero 2007; Săvescu Ciucivara 2007; Rezac 2008; Manzini 2013). However, the PCC cannot be considered a peculiarity of Romance clitic combinations, as similar phenomena are attested in languages with rich agreement systems as well (Adger and Harbour 2007; see Haspelmath 2004 for a typological survey and a tentative frequency-based analysis).

Within the generative framework, both morphological and syntactic accounts of the PCC have been advanced. Morphological accounts argue that the constraint is due to a post-syntactic filter preventing certain clitic pronouns or agreement affixes from co-occurring (Perlmutter 1971). In Distributed Morphology (see Bonet 1991; 1995; among others), the constraint filters certain feature bundles at the syntax/PF interface: this hypothesis explains why certain combinations of clitic pronouns or agreement markers are subject to the constraint although the corresponding featural configuration is, in principle, syntactically licit.

Alternatively, we might argue that the constraint follows from an agreement restriction (lato sensu) which occurs in syntax as a consequence of a multiple agree configuration (Anagnostopoulou 2003; 2005; Adger and Harbour 2007; Nevins 2007; among others) or of a minimality restriction (Bianchi 2006; Săvescu Ciucivara 2007). Anagnostopoulou (2003) argues that the PCC arises as two goals compete to check the same features against a single probe: in a nutshell, let us suppose that both objects have to check against a head endowed with an unvalued/uninterpretable feature F: if the indirect object checks F, the direct object cannot enter an agree relation with the same probe and consequently the derivation ends up crashing. Conversely, if the indirect object does not check the feature F, the sentence is grammatical as the direct object is allowed to enter the agree relation. According to this kind of explanation, the PCC ultimately resides on the featural specifications of each element: F clitics do trigger the PCC, while non-F clitics (hence, $3 p$ accusative clitics) can occur in any type of combination.

The fact that the constraint is subject to cross-linguistic variation (for instance, Rumanian allows some combinations that are banned in the other Romance languages; see Săvescu Ciucivara 2007) may be problematic for accounts suggesting that the restriction follows directly from a basic mechanism of narrow syntax. To overcome the objection, we can either argue that cross-linguistic variation depends on the featural specifications of each item (i.e., on whether or not the clitic bears a valued/interpretable feature F) or, following Nevins (2007), that the agree relation is parametrized: F stands for a constellation of binary features and, given a specific feature (e.g., 
[participant]), the probe can search for a single value (positive, negative, or constrastive) of that specific feature.

Bianchi (2006) departs from a multiple agree analysis and argues instead for an explanation based on Rizzi's Relativized Minimality. She proposes that each clitic pronoun is in a dependency relation with a Person head in the CP layer. As Person projections are rigidly ordered in a cartographic-like fashion, either the dependency relations in ditransitive constructions may cross each other as in (2a) or one may be nested into the other as in (2b). In the latter configuration, Relativized Minimality is violated as the lower clitic enters a dependency with the higher PersonP rather than with the nearest one:

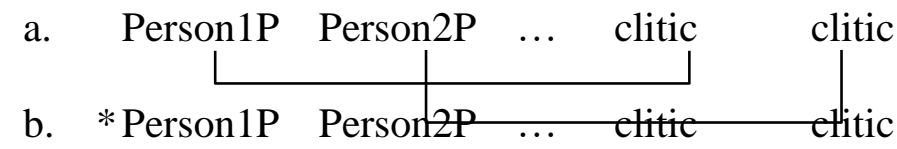

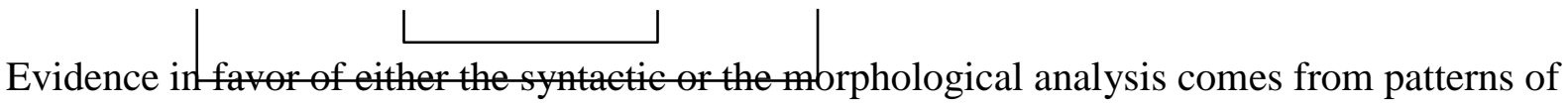
PCC avoidance, that is, morphological or syntactic constructions occurring instead of clitic combinations which would violate the PCC. In fact, the Romance languages vary with respect to the way in which they prevent a PCC violation.

Bonet $(1991,204)$ noticed that, to avoid a PCC violation, in Spanish the dative clitic is replaced by a morphologically strong pronoun, which, in such cases, is not mandatorily focused. For instance, in (3a), a PCC environment, the dative clitic can be replaced by a non-focused strong pronoun, while in (3b), where the PCC does not hold, the strong dative pronoun is mandatorily focused (conventionally, focus is represented with capital letters): ${ }^{1}$
a. me (*le) recomendaron a él/ÉL $\mathrm{Me}=(*$ to.him $)=$ recommended.they to him 'they recommended me to him'

b. lo recomendaron a *él/ÉL it/him $=$ recommended.they to him 'they recommended it/him to him'

Another strategy to avoid PCC violations is the replacement of the $3 p$ dative clitic with a locative exponent. This pattern is allowed in Berceloní Catalan (Bonet 1991, 209; 2008) and, marginally, in regional varieties of Italian (Pescarini 2010) and French (Rezac 2010). In the Catalan variety spoken in Barcelona, for example, the $3 p$ dative clitic $l i$ can be replaced by the locative item $h i$ in PCC environments (in other contexts, the same substitution results in ungrammaticality):

$$
\begin{aligned}
& \text { A en Pere } \mathbf{m} \text { ' hi/*li va recomanar en Josep. } \\
& \text { To the Pere me }=\text { there } / * \text { to.him }=\text { goes recommend the Josep } \\
& \text { 'Josep recommended me to him (Pere).' }
\end{aligned}
$$

The PCC, however, is not the only restriction exhibited by clitic combinations. In fact, some clitic combinations are banned on a language-specific basis, depending exclusively on the morphological shape of the clitic exponents. For instance, many Romance languages tend to avoid sequences of identical exponents (Menn and MacWhinney 1984; Grimshaw 1997; 2000; Ackema 2001; Neeleman and van de Koot, this volume). The following Italian examples show that the locative clitic $c i$ is free to combine with any other clitic, save for the identical $1 \mathrm{pl}$ clitic $c i$ (see (5c)): 
(5) a. mi ci porta Micol

b. ti ci porta Micol

c. (*ci) ci porta Micol

d. vi ci porta Micol

$\mathrm{CL}=$ there $=$ brings Micol

'Micol takes me/you/*us/you.pl there'

Conversely, in languages in which the same clitics are not identical - as in French, in (6b) - the corresponding combination is possible. It means that the above restriction does not follow from any general syntactic constraint, but it is due to a language-specific morphological condition.

(6) Italian

a. $\quad(* \mathbf{C i})$ ci potete portare?

there $=$ us $=$ can.you take

'Can you take us there?'

French

b. Pouvez-vous nous y conduire?

can-you us $=$ there $=$ take

'Can you take us there?'

Notice, however, that the ban on identical exponents is not universal: there are northern Italian dialects, for instance, in which two identical $s e$ 's, one reflexive and one impersonal, can co-occur. Nonetheless, the tendency to avoid sequences of identical elements is undeniable and the purely morphological nature of the process is quite self-evident. In some cases, however, it is rather questionable whether a given sequence is ruled out because of the co-occurrence of identical elements or, rather, because of an orthogonal syntactic restriction as I will argue in section 2.3.

\subsection{Order}

The internal order of clitic sequences (namely, the order of clitics with respect to other clitics) represents a challenge for any syntactic account, as clitic elements are rigidly ordered on a language-specific basis as exemplified in (7) and (8).

(7) Italian
a.
glielo
danno
Dat Acc

to.him/her/them-it/him= give. they

'they give it/him to him/her/them'

French
b. ils le lui donnent
they $=\mathrm{it} / \mathrm{him}=$ to.him $/$ her $=$ give
'they give it/him to him/her'
Acc Dat

(8) Italian
a. le si parla
to.her $=$ one $=$ speaks
'one speaks to her'

Spanish

"one speaks to her'
b. se le habla
one $=$ to.him $/$ her $=$ speaks
'one speaks to him/her'

Dat Imp 
To the best of my knowledge, there are few synchronic accounts linking the order of clitics to other syntactic phenomena (see Somesfalean 2005). ${ }^{2}$ In particular, given such an impressive degree of variation, it is usually claimed that no principled explanation can link the order of pronominal clitics within a cluster with the order of the corresponding nominal elements in the clause. Rather, clitics seem to occupy dedicated positions, whose order is set on a language-specific basis. The nature of these positions, however, is a question that is debated much more and that has been addressed from at least two points of view: we can try to derive the surface order via syntactic principles or, alternatively, postulate an intermediate level of representation mapping syntactic structures into linear sequences by means of surface constraints (Perlmutter 1971), morphological templates (Bonet 1991; 1995), precedence conditions (Harris 1994), Optimality Theory constraints (Heap 1998), etc.

However, in light of both empirical and theoretical advances, it seems to me that the theoretical need for extrasyntactic computation has progressively diminished. On the empirical side, several varieties allowing optional orders have been discovered: for instance, as we will see in the following section, many Romance languages have exhibited optional orders for centuries before establishing the rigid ordering attested in the modern age. This kind of evidence ends up challenging templatic accounts, which exclude the possibility of cyclical reordering (Radford 1977). On the theoretical side, in the last decades our knowledge of syntactic structures has radically improved, leading to a detailed and rich cartography of functional elements (Cinque and Rizzi 2010). Fine-grained maps have been proposed also for Romance clitics (Poletto 2000; Manzini and Savoia 2002; 2004; Tortora 2002; Bianchi 2006; Săvescu Ciucivara 2007; Benincà and Tortora 2009; 2010). Given a much richer structure, we can capture cross-linguistic differences by supposing that not all the clitic positions are occupied simultaneously and, consequently, that variation arises as a consequence of language-specific parameters.

One might argue that differences in order depend on cross-linguistic variations in the denotational properties of each clitic element. In compliance with the so-called Borer-Chomsky conjecture (Baker 2008), we may in fact think that all the parameters of variation are attributable to differences in the features of particular items in the lexicon. This type of explanation is advanced by Manzini and Savoia (2004), who argue that the denotation of a specific morphological item can vary cross-linguistically and, as a consequence, its position within the universal hierarchy can be subject to variation. Take, for instance, the Italian dialects spoken in Vagli and Olivetta San Michele. The former exhibits the order dat $>$ acc, while the latter shows the opposite pattern. According to Manzini and Savoia's analysis, the distinction results from the denotational properties of the $3 \mathrm{p}$ accusative clitics $l$ and $u$, which lexicalize different features (respectively, $\mathrm{N}$ and $\mathrm{R}$ in Manzini and Savoia's representation) and, consequently, have different positions in the clitic string:

(9) Italio-Romance: Vagli, Tuscany

a. $\quad i \quad f i \quad l \quad \partial a$

he $=$ to.him $=$ it $=$ gives

'he gives it/them to him'

b.<smiles>[R][R10](=[V])I</smiles>

(10) Italo-Romance: Olivetta San Michele, Liguria

a. el $u$ duna

he $=\mathrm{it} / \mathrm{him}=$ to.him $/$ her $/$ them $=$ gives

'he gives it/them to him' 
b. $\quad \ldots$ R Q P Loc N I

This analysis is rather appealing in dialects such as those of Vagli and Olivetta, where the order of clitic elements is rigid and the clitic elements are morphologically different. Otherwise, it seems to me that a lexicalist account, where differences in order result directly from differences in denotation, suffers from the same drawbacks as the templatic approach. Consider, for instance, a language like modern French, which allows both the combinations in (11) (even if the latter must be preferred according to prescriptive grammars).
(11) a. Je te jure, j' en $\mathbf{y}$ ai vu trois.
$\mathrm{I}=$ to.you $=$ swear, $\mathrm{I}=$ of .them $=$ there $=$ have seen three
'I swear, I saw three of them there.'

b. Je te jure, j' $\mathbf{y}$ en ai vu trois.

$\mathrm{I}=$ to.you $=$ swear, $\mathrm{I}=$ there $=$ of. them $=$ have seen three

'I swear, I saw three of them there.' (Rezac 2010)

Under a lexicalist account, we should postulate two y's (or two en's) with different featural contents. Most importantly, though, we would expect that differences in ordering had interpretive consequences, which is not the case.

Alternatively (and without excluding a priori that the Lexicon could play a role in ordering phenomena), we can argue that such alternations are due to a structural ambiguity between two possible structures, as proposed by Kayne $(1994,19-21)$ as a corollary of his antisymmetric theory. He predicts that two (or more) clitics can be either split or clustered, as in (12a) and (12b) respectively. In the former case, clitics occupy distinct syntactic projections; in the latter, the leftmost clitic is left adjoined to the other.

$$
\begin{array}{ll}
\text { a } & {[\mathrm{cl} \ldots[\mathrm{cl} \ldots]]} \\
\text { b. } \quad[[\mathrm{cl}[\mathrm{cl}]] & \ldots]
\end{array}
$$

A corollary of the theory is that opposite orders, such as $\langle\alpha \beta\rangle$ and $\langle\beta \alpha\rangle$, may result from different syntactic configurations (split vs. cluster) of the same clitic material:

$$
\begin{array}{ll}
\text { a. } & {[\alpha \ldots[\beta \ldots]]} \\
\text { b. } & {[[\beta[\alpha]] \ldots]}
\end{array}
$$

The proposal will be discussed in greater detail from section 3 onwards.

\subsection{Opacity}

In many Romance languages, clitic clusters are frequently targeted by unexpected substitutions, making the resulting shape of the combination opaque. In Italian, for instance, combinations of identical clitics are avoided by replacing the leftmost element of the cluster with a dummy exponent $c i$. Noticeably, these substitutions never affect the intended meaning of the combination. 


$$
\begin{aligned}
& \mathbf{C i} /{ }^{*} \mathbf{s i} \quad \text { si } \quad \text { lava } \quad \text { ogni giorno. } \\
& c i /{ }^{*} \text { himself= one= wash.3.sG every day } \\
& \text { 'You wash everyday.' }
\end{aligned}
$$
b. Ce/*ne ne escono molti.
$c e / *$ from.there $=$ of-them $=$ come-out.3.PLmany
'Many of them come out from there.'

The opacity of clitic sequences is arguably related to syncretism, namely the presence of a single morphological exponent expressing different syntactic elements. Italian, for instance, exhibits a syncretic clitic $c i$, which stands for various types of PPs (including locatives) and references 1pl objects. If we compare Italian with Latin or other Romance languages, we note that the syncretism arose because the etymological $1 \mathrm{pl}$ form was replaced by a reflex of a locative particle:

\begin{tabular}{|l|l|l|}
\hline Latin & French & Italian \\
\hline IBI/ECCE-HIC & $y$ & \multirow{2}{*}{$c i$} \\
\cline { 1 - 2 } NOS & nous & \\
\hline
\end{tabular}

In the Distributed Morphology literature (Bonet 1991; Calabrese 1994; Harris 1994), both the contextual substitutions in (14) and the absolute one in (15) have been analyzed as consequences of the same phenomenon, that is, the occurrence of post-syntactic operations manipulating syntactic features before morphological exponents are inserted. To support a post-syntactic analysis, Pescarini (2010) showed that there is a strong correlation between contextual and absolute syncretism, as the unexpected clitic appearing in opaque clusters is often a syncretic one. Alternatively, Kayne 2008 argued for a syntactic explanation based on the hypothesis that syncretism is an epiphenomenon due to the presence of a silent element licensed by what seems to be a syncretic element.

As for the causes of opacity and syncretism, Calabrese $(1994 ; 2008 ; 2011)$ argued for a series of filters disallowing certain bundles of syntactic features at the syntax/PF interface. Once the filter is violated, post-syntactic operations modify the offending feature bundle in order to overcome the filter; the manipulation causes the insertion of an unexpected exponent.

In some cases, such as those in (14), it is rather plausible that the opacity is triggered by the identity avoidance principle illustrated in section 2.2 (Grimshaw 1997; 2000; Pescarini 2010; among others).

Not all the cases of opacity, however, result straightforwardly from a ban on sequences of identical exponents. For instance, in Spanish the dative clitic $l e(s)$ is replaced by the $3 p$ reflexive se whenever it combines with a $3 p$ accusative clitic as in (16a). Similarly, in Italian the feminine clitic $l e$ is replaced in synchrony by its masculine counterpart $g l i$ in the same context, see (16b).

$$
\begin{aligned}
& \text { a. Juan se/*le lo comprò. } \\
& \text { Juan } s e / * \text { to.him/her= it= bought } \\
& \text { 'Juan bought it for him/her/them.' } \\
& \text { b. Gianni glie/*le lo comprò. } \\
& \text { Gianni glie/*to.her= it= bought } \\
& \text { 'Gianni bought it for her.' }
\end{aligned}
$$

The pattern above may follow from a ban on the co-occurrence of two identical formatives $l$ - within the same clitic sequence. This account, however, appears to be rather naïve. Consider, for instance, 
the following example from Italian, which shows that the same pattern of substitution is found in front of the clitic ne. In (17), no identity-avoiding principle can be responsible for the substitution.

$$
\begin{aligned}
& \text { Gianni glie/*le ne comprò. } \\
& \text { Gianni to.him/her= of.it/them= bought } \\
& \text { 'Gianni bought it for him/her/them.' }
\end{aligned}
$$

Moreover, the morphological irregularities in (16) and (17) do not seem syntactically "inert." Consider, for instance, a language like Italian, which - unlike Spanish - does not admit clitic doubling:

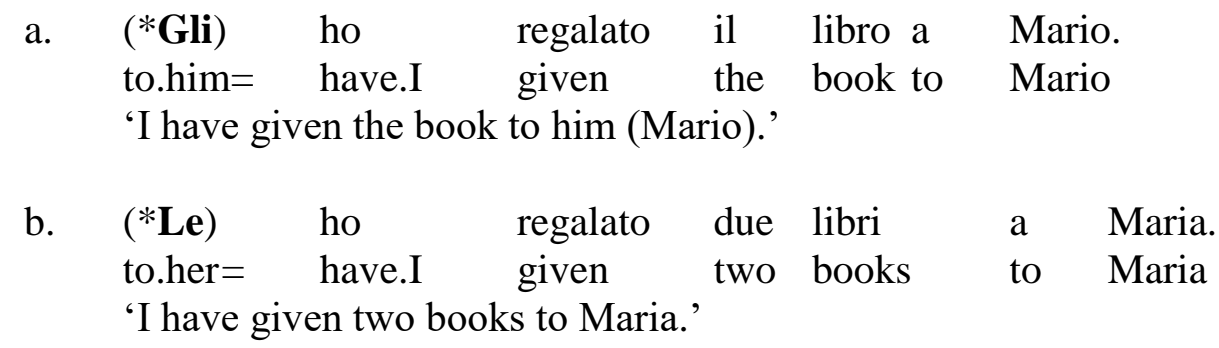

However, as noticed by Benincà $(1988,137)$, doubling is exceptionally allowed when the $3 p$ dative is clustered with a $3 p$ accusative or partitive clitic, namely in the same environment characterized by morphological opacity; see (19):
Glie $=$ l' ho
regalato
a Mario.
to.him=it= have.I given to Mario
'I have given it to him (Mario).'
b. Glie =ne ho regalati due a Maria. to.him=of.them/it= have.I given two to Maria 'I have given two of them to her (Maria).'

This is symptomatic of the peculiar status of these combinations, which may follow from their syntactic nature.

\section{Diachrony}

As previously mentioned, clitic elements are generally clustered together in a rigid order, which varies on a language-specific basis. Synchronic variation results from diachronic changes, which, in some Romance languages but not in others, made clitic combinations evolve from the archaic order accusative > dative to the opposite one. Descriptively, in the earliest stages, clitics had the same order as the corresponding arguments, with direct objects preceding datives. As a consequence of the change, the order of clitic elements ends up mirroring (in Baker's 1985 terms) that of their nominal counterparts.

In Italian, French, and Catalan, this change dates back to the Middle Ages, while in other Romance areas (like part of the Iberian peninsula) the only possible order has been dative > accusative since the earliest attestations. One may wonder if the latter varieties had undergone a similar change in an undocumented stage, as proposed for northern Italian dialects (Melander 1929). 
The order accusative $>$ dative is retained in French when both clitics are $3 p$, while very few dialects still display the (alleged) archaic order with 1/2p dative clitics. Leaving aside the case of French imperatives (see section 7), this pattern is attested in a group of the dialects of western Italy, like the aforementioned dialect of Olivetta San Michele (Borgogno 1972; Manzini and Savoia 2004; Parry 2005, 268 fn. 38).

$$
\begin{aligned}
& \text { Italo-Romance: Olivetta San Michele, Liguria } \\
& \text { el u mə duna } \\
& \text { he }=\text { him/it= to.me= gives } \\
& \text { 'he gives him/it to me' (Manzini and Savoia 2004) }
\end{aligned}
$$

Hence, synchronically, the archaic order (namely, accusative $>$ dative) is extremely rare when the dative is $1 / 2 p$ or $3 p$ reflexive, while it is more common with combinations of $3 p$ pronouns. This asymmetry is reminiscent of Kayne's (2000) distinction between determiner and person clitics: the former are $3 p$ non-reflexive forms, which usually resemble the morphology of definite articles in having a bimorphemic structure. Determiner clitics, unlike person clitics, can be decomposed into a root $(l-)$ followed by an ending expressing gender and number agreement. The mirror order is therefore disfavored when the dative element is a determiner clitic.

The asymmetry is confirmed by the data about the diachronic evolution. The change with $1 / 2 p$ datives (and the $3 p$ reflexive clitic $s e / s i$ ) is neat and relatively sudden, while the evolution of $3 p$ clitics is delayed and, if it takes place, it is more intricate (see below).

In Italian, the evolution of 1/2p datives is straightforward. The earliest records exhibit the archaic order, in (21a), while, in the first half of the fourteenth century, both orders were allowed, in apparent free variation. Later on, however, the archaic order was progressively replaced by the innovative mirror order, in (21b), which is the only possible order in present-day Italian. ${ }^{3}$ French, in (22), shows the same evolution, which dates from the sixteenth century.

(21) a.

$$
\begin{aligned}
& \text { che }[\ldots] \text { voi la mi concediate Acc Dat } \\
& \text { that }[\ldots] \text { you.PL it.F= to.me= grant.SBJV } \\
& \text { 'that you grant it to me' (Boccaccio, Filocolo 212) }
\end{aligned}
$$
b. se Egli me la concede Dat Acc
if $\mathrm{He}$ to.me= it.F= grants
'if He grants it to me' (Boccaccio, Filocolo 72)

(22) Old French
a. Je le te comande.
$\mathrm{I}=\mathrm{it}=$ to.you $=$ order
'I order it to you.'
Modern French
b. Je te le comande. Dat Acc
$\mathrm{I}=$ to.you $=\mathrm{it}=$ order
'I order it to you.'
Acc Dat

A similar change has affected combinations containing the clitic en/ne. ${ }^{4}$ With $1 / 2 p$ datives, the order is always dative $>n e$ since the earliest attestations. Differences between medieval and modern varieties are found in combinations including a $3 p$ dative element (Italian) or a locative clitic (French). In modern Italian, ne must follow the dative clitic, while in Old Italian $n e$ can either follow or precede the dative clitic as illustrated in (23). 
(23)

e assai ne gli piacquero

and many of.them to.him pleased.3PL

'and he liked many of them' (Boccaccio, Decameron II, 5)

b. rimasero cimque fior. d' oro, ed io gli ne rendei quatro remain five florin of gold, and I to.him of.them gave.back four 'there remained five florins and I gave him four (florins) back' (in Castellani 1952: 633

1)

In Old French, the clitic en precedes the locative clitic $i$ (Foulet 1919, §436). The same order is still allowed in modern French (Rezac 2010), although the opposite one (y en) is found as well; see (11), repeated here as (24b). The latter is normally considered the normative variant.
a. Je te jure, $\mathrm{j}^{\prime}$ en $\mathbf{y}$ ai vu trois.
$\mathrm{I}=$ to.you $=$ swear, $\mathrm{I}=$ of $\cdot$ them $=$ there $=$ have seen three
'I swear, I saw three of them there.'
b. Je te jure, j' $\mathbf{y}$ en ai vu trois.
$\mathrm{I}=$ to.you $=$ swear, $\mathrm{I}=$ there $=$ of. them $=$ have seen three
'I swear, I saw three of them there.' (Rezac 2010)

The changes illustrated above take place suddenly (see Melander 1929 for Italian,

Meklenborg Salvesen 2011 for French) and consistently; that is, within the same variety, several types of clitic combinations - though not all - were inverted. We are therefore dealing with a single parametric change affecting various clitic combinations.

Building on Kayne (1994, 19-21), one can argue that the change leading to the mirror order is due to the left-adjunction of the dative clitic to the accusative one: in origin, clitics were split and, after the change, they ended up forming a cluster (in Kayne's terms) ${ }^{5}$ cf. (13). Arguably, the trigger of the change was the evolution from weak to clitic pronouns, which allowed clitics (namely, $\mathrm{X}^{\circ} \mathrm{s}$ ) to left-adjoin one to the other (with the noteworthy exception of French 3p datives; see section 7).

\section{Climbing}

In principle, one would expect split combinations to be separated in those contexts in which different placement sites are allowed, as in certain restructuring contexts (Rizzi 1982). Given the split/cluster hypothesis, the prediction is that, with split combinations, one clitic can climb leaving the other behind.

In fact, in modern Italian, the separation is tolerated, in a colloquial register, only with certain combinations. Crucially, the combinations allowing the separation are those that, in the Middle Ages, were not targeted by the change leading to the mirror order:

(25) a. ${ }^{\%}$ si può portar=lo domani (cf. lo si può portare domani) ${ }^{6}$

one can take=it tomorrow

'we can take it tomorrow'

\footnotetext{
${ }^{1}$ Libro del dare e dell'avere di Noffo e Vese figli di Dego Genovesi. In Nuovi testi fiorentini del Dugento, ed. by Arrigo Castellani, Firenze, Sansoni, 1952)
} 

b. ${ }^{\%} \mathbf{t i}$ posso portar $=\mathbf{c i}^{2}$
you $=\mathrm{I}$.can $=$ take $=$ there
'I can bring you there'

c. ${ }^{\%}$ c' ha dovuto portar $=$ mi un'amica

there has had take=me a friend.F

'a friend of mine had to take me there'

On the contrary, the combinations that in the past underwent the change leading to the mirror order are nowadays inseparable. The separation of the clitics in (26), for instance, gives rise to severe ungrammaticality.

\section{a. *Carlo si può portar=lo domani (cf. ${ }^{\vee}$ Carlo se lo può portare ...) \\ Carlo for.himself can take $=$ it tomorrow \\ 'Carlo can take it for himself tomorrow'}
b. *lo ha dovuto portar=ci un'amica ${ }^{7}$ (cf. ${ }^{\vee}$ ce l'ha dovuto portare ...) him/it has had take=there a friend.F
'a friend of mine had to take it/him there'

This supports the hypothesis that the combinations that in the fourteenth century changed their order behave nowadays as clusters. By contrast, those combinations that have kept the original order - which therefore correspond to a split configuration - are nowadays marginally separable.

Furthermore, it is worth noting that Old Italian - in the chronological stage in which the order accusative $>$ dative was still in use - was more liberal than modern Italian with respect to separation, as illustrated with the causative construction (27), where a $1 / 2 p$ dative clitic and a $3 p$ accusative occur in a split configuration: ${ }^{8}$

(27) a. Ma la cosa incredibile mi fece

But the thing incredible me made

'But your plight, which defies belief, made me

Indur=lo ad ovra ch' a me stesso pesa
induce=him to work that to my self weighs
urge him to perform/do this deed that weighs on me' (Dante, Inferno 13, 50-51)

The fact that Old Italian clusters can be separated is consistent with the hypothesis that clitic combinations were originally split and only later on began to form a single syntactic unit. This happened when clitic combinations evolved from the structure-preserving to the mirror order. In fact, the sequences that did not undergo this change can still be separated also in modern (colloquial) Italian.

\section{Restrictions and repairs}

In section 1, it was observed that in many languages combinations of $3 p$ clitics are morphologically opaque, as the co-occurrence of two $l$-formatives is banned. In a number of Romance varieties, the etymological form li/le is replaced by another clitic item, subject to cross-linguistic variation: it may

\footnotetext{
${ }^{2}$ www.efpfanfic.net > Fanfic su artisti musicali > One Direction retrieved by Google 13.08.16.
} 
correspond to the $3 p$ reflexive clitic (as in Ibero-Romance and Campidanese Sardinian), to the locative clitic (as in many Italo-Romance dialects, Logudorese Sardinian, and Catalan), and, rarely, to the partitive/genitive clitic (as in some southern Italian dialects).

(28) Spanish
a. Juan se/*le lo comprò.
Juan to.him/her= it= bought
'Juan bought it for him/her/them.'
Italo-Romance: Logudorese Sardinian
b. bi/*li l' appo datu
to.him/her/them $=\mathrm{it}=$ have.1.SG given
'I gave it to him/her/them' (Jones 1993, 220)
Italo-Romance: Rocca Imperiale
c. $\mathbf{n} / * \mathbf{i} \quad \mathbf{u}$ da
to.him/her/them $=$ it= gives
'he/she gives it to him/her/them' (Manzini and Savoia 2005, 291)

As previously noticed, these irregularities cannot follow from any morphological constraint. Rather, they may be symptomatic of the syntactic make-up of the cluster, as they seem to be related to the surfacing linear order of clitic elements. Given the hypothesis that the order dative > accusative is derived via incorporation, it follows that opacity arises because $3 p$ dative clitics (e.g., Spanish le 'to him/her') - which are bimorphemic determiner clitics (Kayne 2000) - cannot be incorporated.

Manzini and Savoia (2005, §4.5.4), however, observe that such irregularities are displayed even by those dialects in which the dative clitic has a monomorphemic shape, such as $i<$ Latin ILLI. However, one could object that the type of irregularity we observe in present-day dialects originated when $3 p$ clitics were bimorphemic; for example, before an independent rule of aphaeresis made the clitic $l i$ become $i$. Data from medieval texts seem to confirm this reconstruction (Pescarini 2014).

To support the claim that opacity follows from root incorporation, however, one has to depart from Kayne's view in adopting a Late Insertion model. If we assume, in accordance with Halle and Marantz (1993), that all syntactic operations manipulate bundles of $\Phi$-features, while morphological exponents are inserted at the syntax/PF interface, we can in fact explain why incorporation results in a morphological irregularity. The hypothesis is as follows: as a consequence of root incorporation, the agreement features of the lower clitic are left behind and this prevents bimorphemic elements from occurring in the first position of the cluster. In fact, the bare root of the dative clitic cannot trigger the insertion of the exponent $l$ - (which must combine with a proper ending); rather, a dummy monomorphemic exponent, subject to linguistic variation (Pescarini 2010), is inserted giving rise to the observed opacity (it is worth recalling that, in the same context, monomorphemic clitics are free to occur). In Spanish, for instance, a dummy clitic se is inserted instead of the expected determiner clitic; see (29). It is worth noting that the Romance languages vary with respect to the form of the dummy clitic (on the nature of the dummy, see Pescarini (2010)).

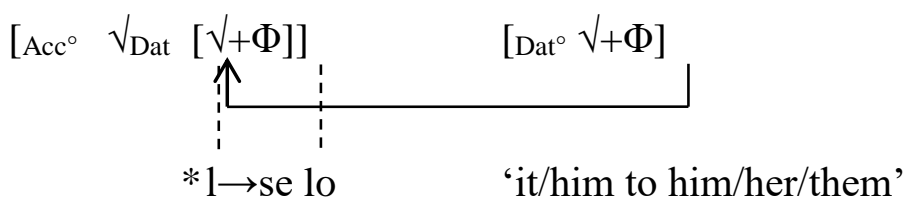

This scenario is confirmed by the fact that these substitutions take place in combinations with the mirror order. In several Sardinian dialects, for instance, the bimorphemic form $l i$ is free to occur in isolation (namely, without co-occurring with another clitic) or in cluster-final position, as in (30a) 
and (30b) respectively. However, the bimorphemic $l i$ cannot occur in cluster-initial position, where it is replaced by the "spurious" exponent $b i$.

(30) Italo-Romance: Sardinian (Ittiri; Padria; Luras; Siniscola; Galtellì; Bosa)
a. li dana kustu
to him/her= gives this
'he/she gives this to him/her
b. nde li dana
of.them $=$ to.him/her $=$ gives
'he/she gives some of them to him/her'
c. bi/*li lu dana
to.him/her $=$ it $=$ gives
'he/she gives it to him/her' '(Manzini and Savoia 2005, II: 317.321)

The analysis is that (30b) shows the archaic order - the one attested in medieval vernaculars because the two clitics stand in a split configuration; see (31a). The split dative clitic can be realized by a composite item like singular $l i$, plural lis. In combination with an accusative clitic, by contrast, the combination takes the opposite configuration, with the dative clitic incorporating on the accusative one. As a consequence of the incorporation, the dative is expressed by a dummy monomorphemic exponent instead of the expected composite one:

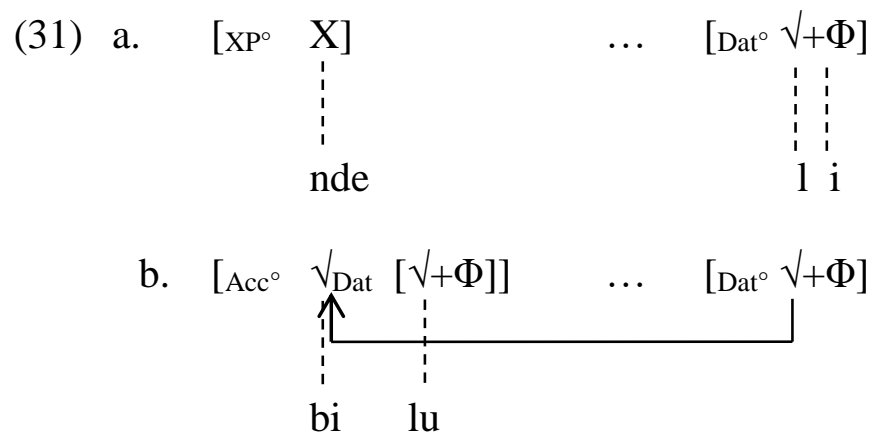

Furthermore, the above explanation may account for the observed asymmetry between determiner and person clitics with respect to diachronic evolution: clusters are more likely with person dative clitics (e.g., $m e, s e$, etc.) rather than with determiner clitics. It is reasonable to think that this asymmetry has to do with the composite nature of determiner clitics (Kayne 2000), which hinders their incorporation.

Moreover, the cluster analysis is supported by the phenomenon of parasitic plural (Halle and Harris 2005; Manzini and Savoia 2009; Kayne 2010): in languages with sigmatic plural, 3p datives are replaced as usual when clustered, but their plural feature is expressed by $-s$, which shows up unexpectedly in cluster-final position, after the $3 \mathrm{sg}$ clitic $l o$.

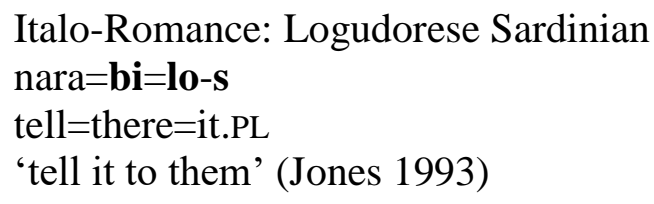


Following the above analysis, the position of the plural suffix $-s$ can be accounted for as an instance of stranding of the agreement features of the dative pronoun, whose root has incorporated into the accusative clitic $l o$ :

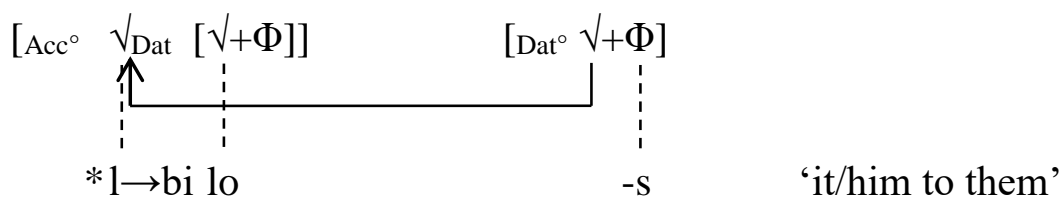

The position of the plural ending is therefore a clue to incorporation, which strengthens the hypothesis of a correlation between ordering and morphological irregularities. In particular, the data above support the claim that the mirror order is due to the incorporation of the (root of the) dative clitic on the accusative. Further evidence in favor of this account comes from the behavior of clitic doubling in Italian.

\section{Clitic doubling}

This section aims to show that the hypothesis of root incorporation provides a straightforward account of the exceptional case of doubling shown in Italian. Recall that Italian has two 3p dative forms (masculine gli and feminine le) $:^{9}$

(34) a. Gianni glie/*le lo comprò.

Gianni to.him/her= it= bought

'Gianni bought it for him/her/them.'

b. Gianni glie/*le ne comprò due.

Gianni to.him/her= of.it/them= bought two

'Gianni bought two of it/them for him/her/them'

In light of the above analysis, this means that gli, unlike $l e$, counts as a monomorphemic element, which can undergo incorporation. This is confirmed by the fact that, in a low register, gli functions as an underspecified pronoun which can reference also feminine or plural entities.

Colloquial Italian

Gianni gli= ha dato un bacio (a lui/lei/loro).

Gianni to.him has given a kiss (to him/her/them)

'Gianni kissed him/her/them.'

Crucially, when incorporated, gli can double a dative DP:
a. Glie l' ho regalato a Mario.
to.him= it=have.I given to Mario
'I have given it to him (Mario).'
b. Glie ne ho regalati due a Maria. to.him $=$ of.them/it= have.I given two to Maria 'I have given two of them to her (Maria).'


Conversely, when it occurs in a split configuration, it can alternate with its feminine counterpart (le), but it cannot double any DP:
a. gli/le si presenta Luca (*a Mario/Maria)
to.him/her= one $=$ introduces Luca (to Mario/Maria)
'we will introduce Luca to him/her (Mario/Maria)'
b. gli/le ci attacco un cartello (*per Mario/Maria) for.him/her $=$ there $=$ hang.I a sign (for Mario/Maria) 'I'll hang a sign there for him/her (Mario/Maria)'

This entails a correlation between opacity and doubling as the latter is allowed only in opaque clusters. The analysis is as follows. When clustered, the clitic gli stands for a bare root, which is incorporated on the accusative or the partitive clitic. As illustrated in the following scheme, the root of the dative clitic is adjoined to the other clitic, while its agreement features are stranded:

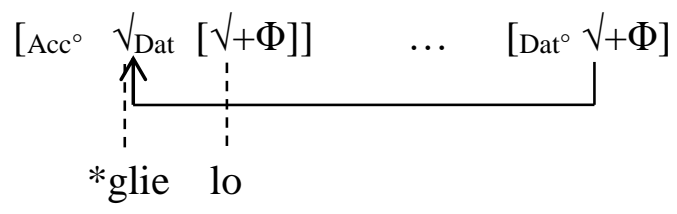

Otherwise (in split sequences or when it occurs without other clitics), gli occupies a dedicated position. Hence, differently from above, the dative clitic gli realizes not a bare root, but a root plus a complete set of phi-features.

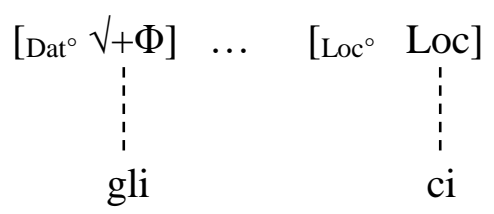

The difference between (38) and (39) is the cause of the asymmetry with respect to clitic doubling. Doubling is tolerated when gli is clustered because, as a bare root, it cannot function as a true doubler. In (39), conversely, gli stands for a full-fledged determiner clitic, which is incompatible with a co-occurring DP.

Furthermore, notice that the same alternation and the same behavior with respect to doubling are found in the following sequence of three clitics, ${ }^{10}$ although the dative clitic is not adjacent to the accusative one:

$$
\begin{aligned}
& \text { ?'Gianni gli/*le ce ne comprò due. } \\
& \text { Gianni to.him/her= there= of.it/them= bought two } \\
& \text { 'In that place, Gianni bought two of it/them for him/her/them.' }
\end{aligned}
$$

According to the previous analysis, the conclusion is that the cluster above is formed by cyclic incorporation of one clitic on the other.

\section{French}

French differs from the other Romance languages in two main aspects. First, the order of combinations of $3 p$ clitics is still accusative $>$ dative and, second, the morphology of the cluster is 
transparent. Under the previous analysis, it is not surprising that these two aspects go hand in hand, as the presence of morphological irregularities is arguably linked to the establishing of the mirror order.

Historically, though, the evolution of the French clitic system is not as linear as it appears at first glance. As previously mentioned, the original $3 p$ dative clitic $l i$ ('to him/her') has been replaced by the form lui, which is not a regular reflex of the Latin dative pronoun ILLI.

(41) Old French
a. Et il li dit:
and he $=$ to.him/her= says
'And he says to him/her:'
Modern French
b. Et il lui dit:
and he= to.him/her= says
'Ad he says to him/her:'

Noticeably, the form lui was attested in old French, but it functioned as a strong pronoun, as it also does in modern French. The change in (41) can be therefore viewed as the substitution of a clitic element with a morphologically strong pronoun (with a clitic-like syntax): for the rest of this chapter, the term "fake strong" will be used to refer to this type of element, which on the morphological side resembles a strong pronoun, although syntactically it behaves as a clitic one. We can wonder whether a similar change had happened with the plural clitic, which has been lor $(<$ ILLORUM) since the earliest attestations, instead of the expected *lis (< ILLIS).

Again, the etymological dative clitic ends up being replaced by a non-etymological form. However, in French, the morphological shape of the dative clitic is not reduced to a monomorphemic element, but rather is "enriched" to become identical to a strong pronoun. Hence, one might submit the hypothesis that these two processes are two faces of the same coin, that is, a generalized restriction against bimorphemic datives, particularly when occurring in a cluster configuration.

A comparable replacement of a dative clitic form by a fake strong pronoun is synchronically active in modern French when 1/2p datives occur in enclisis. We have seen in section 3 that combinations of $1 / 2 p$ datives and $3 p$ accusatives have the mirror order, as illustrated in (42a). With imperatives, however, the order of the combination is reversed and, moreover, $1 / 2 \mathrm{p}$ clitics turn into fake strong forms, which, as Laenzlinger $(1994,85)$ points out, cannot be focused, modified, or coordinated.

(42) a. Il me le donne.

he to.me it gives

'He gives it to me.'

b. Donne-le-moi!

give $=\mathrm{it}=$ to.me

'Give it to me!'

With enclitics, this may be due to the assignment of stress to the word-final syllable (Foulet 1924). But the same hypothesis cannot hold for $3 \mathrm{p}$ clitics, as the change $l i>l u i$ took place in proclisis as well, where the clitic is not assigned stress.

Laenzlinger (1993) argues that the phenomenon of fake strong pronouns calls for a syntactic explanation which may be related to the issue of cluster formation. The correlation between cluster formation and the morphology of French clitic elements is strengthened once we turn our attention 
to vernaculars and colloquial registers, in which other possibilities are allowed. In fact, in enclisis we find traces of the inverted order, as in (43b). With this order, the form me can occur instead of moi (see (43c)), while, to the best of my knowledge, me cannot occur when the combination has the mirror order as in (43d).
(43) a. Donne-le-moi!
b. Donne-moi-le!
c. Donne-me-le!
d. *Donne-le-me!
'Give it to me!'

According to the above analysis, the patterns in (43) follow from the coexistence of cluster and split sequences, in combination with the syntactic behavior of imperatives (Rooryck 1992; Laenzlinger 1994). The standard variant, in (43a), results from a split combination, with the imperative verb crossing both clitic positions.

$$
\begin{array}{lllllllll}
\text { Donne } & \ldots & \text { le } & \ldots & \text { moi } & \ldots & \mathrm{t} & (=43 \mathrm{a})
\end{array}
$$

The other combinations can be derived from (44) by means of different types of movement. The pattern in (43b) is derived via cyclical movement of the imperative through the clitic positions, while (43c) entails the incorporation of one clitic to the other before the verb moves past (or incorporates onto) the whole cluster:

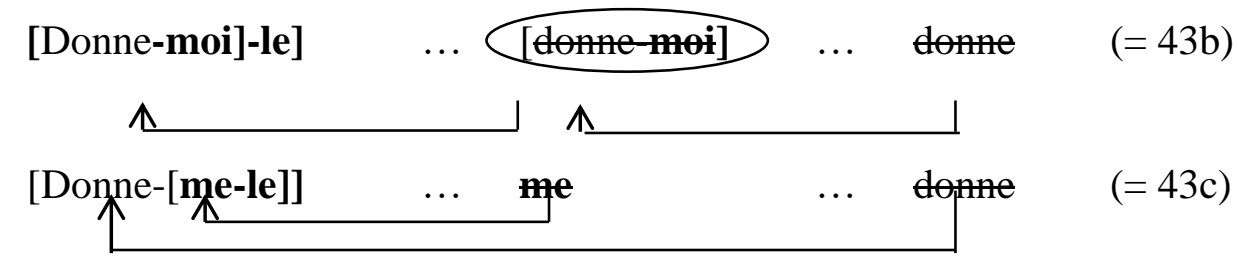

The alternation moi/me reflects the fact that in the former case the order dative $>$ accusative is a side effect of verb movement, while in the latter the two clitics form a cluster independently from verb movement.

The ungrammaticality of the fourth option follows straightforwardly from the model adopted here. In fact, the occurrence of the form $m e$ in a split configuration (hence, in a combination with the accusative $>$ dative order) is predicted to be unattested.

Lastly, the above analysis is consistent with the distribution of liaison, which usually occurs between the imperative form and the clitic en, which begins with a vowel. Things are a bit more complicated with combinations including a fake strong pronoun like moi/toi. As shown below, liaison precedes both clitics when the dative is in cluster-final position, while it occurs between the two clitics in the dialects exhibiting the mirror order. The pattern in (47b) therefore resembles a case of mesoclisis (Manzini and Savoia 2009) as the dative clitic occurs before the segment [z], which originates as a relic of verbal morphology.
a. Parle[z]-en-moi!
b. Parle-moi[z]en!
'Talk to me about it!'

What is of interest here is that the presence of liaison indicates that the sequence moi $+e n$ is not a cluster. Conversely, no liaison is exhibited by those dialects in which the combination has the 
mirror order, but the dative clitic is a full-fledged clitic and, as such, is arguably incorporated on the following one; for example, parle-me*[z]en.

\section{Conclusions}

This chapter has dealt with the morphosyntax of Romance clitic combinations, which show three main peculiarities.

First, many clitic combinations are excluded by various constraints, some preventing combinations of particular $\Phi$-features while others seem sensitive to the morphological exponence of clitics. Among the former, the PCC prevents the co-occurrence of $1 / 2 p$ accusative clitics with a dative clitic. The recent literature has shown that (i) not all the Romance languages share the same pattern of PCC and (ii) the PCC cannot be considered either a Romance-specific or a clitic-specific constraint, as it holds in a number of linguistic families with and without clitics (Haspelmath 2004). Besides PCC-like restrictions, the Romance languages also exhibit a series of further constraints, some of which result from an identity avoidance constraint, which still calls for a principled syntactic explanation.

Second, Romance clitics exhibit various possible orders, a fact that has never been accounted for under a consistent syntactic analysis. Clitic ordering, unlike clitic placement, has received little or no attention in the syntactic literature, while it has become a classic argument in favor of nonsyntactic approaches since Perlmutter (1971). However, once the different patterns displayed by the Romance varieties (including medieval languages and present-day vernaculars) are compared, the scenario appears far from chaotic. In a nutshell, the order of certain clitic combinations is systematically reversed, although the change did not happen everywhere in the Romance domain and, where it happened, it took place in different chronological stages. However, we can recognize a finite number of changes across languages, which, rather than suggesting the existence of various language-specific templates, calls for a unified analysis. This chapter has explored a hypothesis due to Kayne (1994, 19-21), who, as a corollary of his Linear Correspondence Axiom, postulates two possible syntactic configurations for clitic sequences: split or clustered. In the former case, clitics occupy distinct syntactic projections; in the latter, the leftmost clitic is left-adjoined to the other. A corollary of the theory is that opposite orders, such as $\langle\alpha \beta\rangle$ and $\langle\beta \alpha\rangle$, may result from different syntactic configurations (split vs. cluster) of the same clitic material. If so, the history of Romance and consequently, the present-day variation - is due to changes from split to cluster configurations.

The third peculiarity exhibited by Romance clitic clusters is their morphological opacity, that is, the fact that one or more element within the cluster is frequently expressed by a suppletive exponent. In particular, $3 p$ dative clitics are usually replaced by a dummy clitic exponent when preceding another clitic element. Instead of being addressed as morphological idiosyncrasies, the presence of these irregularities may be symptomatic of the underlying syntactic configuration of clitic combinations. In particular, the presence of an opaque form may depend on the adjunction of the dative to another clitic in a cluster configuration.

\footnotetext{
${ }^{1}$ An anonymous reviewer observed that the same does not hold for other Romance languages such as Italian, where a strong pronoun, e.g., lui 'him', is free to co-occur with a focus constituent even if the PCC is not violated. Possibly the peculiar behavior of Spanish has to do with some orthogonal phenomenon (doubling?).
}

(i) a. mi ha raccomandato a lui MIO CUGINO me has recommended to him MY COUSIN 'my cousin recommended me to him'

b. l' ha raccomandata a lui MIO CUGINO her has recommended to him MY COUSIN 'my cousin recommended her to him' 
${ }^{2}$ Meklenborg Salvesen (2011) has observed a direct correlation between the establishing of the dative > accusative order in combinations of complement clitics and the loss of V2 properties in medieval Romance.

${ }^{3}$ Besides the order, (21b) differs from (21a) with respect to the vowel of the dative clitic (me vs mi). On this alternation, see Pescarini (2014).

${ }^{4}$ Different types of ne occupy different syntactic positions as shown by data from (old) Italian and Italian dialects (Manzini and Savoia 2005, §4.5.2). This might give rise to different orders when one $n e$ is combined with other clitic material. To the best of my knowledge, however, the position of the clitic ne with respect to other clitics does not depend on the type of $n e$ involved.

${ }^{5}$ Here I am not committing myself about the layer of the clause in which such a process takes place: it may be either in the argument field in the VP or in a higher field of functional projections dedicated to the placement of clitic material.

${ }^{6}$ Notice that the impersonal si follows the accusative clitic, e.g., lo si, while the reflexive si exhibits the mirror order. Furthermore, it is worth noting that the impersonal clitic must climb in restructuring construction; this is why the counterpart of (26a) with the opposite order of clitics, e.g. *lo può portarsi domani, is ungrammatical. Notice that this is orthogonal to the issue of separability.

${ }^{7}$ An anonymous reviewer noticed that, with the opposite order of clitics, the sentence is degraded but still marginally acceptable, e.g., ?'c'ha dovuto portarlo un'amica. Intuitively, this might suggest that the cluster with the dative is tighter than the one with the locative, but at present I have no principled proposal to capture the asymmetry.

${ }^{8}$ The separation is marginally tolerated also in modern Italian, in rather inaccurate (written?) registers, e.g., *'mi ha fatto odiarlo. With modals, conversely, the separation is always ungrammatical.

${ }^{9}$ Conversely, in various dialects, including the vernacular spoken in Florence, the dative clitic gli does not alternate with a feminine form and clitic combinations are transparent (Manzini and Savoia 2005, 4.4). Arguably, those dialects have a single monomorphemic dative clitic.

${ }^{10}$ This kind of combination is judged very marginal regardless of doubling. 


\section{References}

Ackema, Peter. 2001. "Colliding Complementizers in Dutch: Another Syntactic m-OCP Effect." Linguistic Inquiry, 32 (4): 717-727.

Adger, David, and Daniel Harbour. 2007. "Syntax and Syncretisms of the Person Case Constraint." Syntax, 10 (1): 2-37.

Anagnostopoulou, Elena. 2003. The Syntax of Ditransitives: Evidence from Clitics. Berlin: De Gruyter.

Anagnostopoulou, Elena. 2005. "Strong and Weak Person Restrictions: A Feature Checking Analysis." In Clitic and Affix Combinations, edited by L. Heggie and F. Ordóñez, 49-62. Amsterdam: John Benjamins.

Baker, Mark. 1985. "The Mirror Principle and Morphosyntactic Explanation.” Linguistic Inquiry, 16 (3): $373-415$.

Baker, Mark. 2008. The Syntax of Agreement and Concord. Cambridge: Cambridge University Press.

Benincà, Paola. 1988. "L'ordine degli elementi della frase e le costruzioni marcate." In Grande grammatica italiana di consultazione, edited by Lorenzo Renzi, 115-192. Bologna: Il Mulino.

Benincà, Paola, and Christina Tortora. 2009. "Towards a Finer-Grained Theory of Italian Participial Clausal Architecture." University of Pennsylvania Working Papers in Linguistics, 15: 17-26.

Benincà, Paola, and Christina Tortora. 2010. "On Clausal Architecture: Evidence from Complement Clitic Placement in Romance." In Movement and Clitics: Adult and Child Grammar, edited by Vicenç Torrens, Linda Escobar, Anna Gavarró, and Juncal Gutiérrez, 219-237. Newcastle upon Tyne: Cambridge Scholars.

Bianchi, Valentina. 2006. "On the Syntax of Pronominal Arguments." Lingua, 116: 2023-2067.

Bonet, Eulalia. 1991. "Morphology after Syntax: Pronominal Clitics in Romance." PhD diss., MIT.

Bonet, Eulalia. 1994. "The Person-Case Constraint: A Morphological Approach." MIT Working Papers in Linguistics, 22: 33-52.

Bonet, Eulalia. 1995. "Feature Structure of Romance Clitics." Natural Language and Linguistic Theory, 13: 607-647.

Bonet, Eulalia. 2008. "The Person-Case Constraint and Repair Strategies." In Agreement Restrictions, edited by Roberta d'Alessandro, Susann Fischer, and Gunnar Hrafn Hrafnbjargarson, 103-128. Berlin: De Gruyter.

Borgogno, Giovanni Battista. 1972. "Note di linguistica ligure (in relazione con il dialetto di Perinaldo)." Rivista Ingauna e Intemelia, 27: 69-76.

Calabrese, Andrea. 1994. "Syncretism Phenomena in the Clitic Systems of Italian and Sardinian Dialects and the Notion of Morphological Change." In Proceedings of NELS 25.2, edited by Jill Beckman, 151-174.

Calabrese, Andrea. 2008. "On Absolute and Contextual Syncretism: Remarks on the Structure of Paradigms and on How to Derive It." In The Bases of Inflectional Identity, edited by Asaf Bachrach and Andrew Nevins, 156-205. Oxford: Oxford University Press.

Calabrese, Andrea. 2011. "Investigations on Markedness, Syncretism and Zero Exponence in Morphology." Morphology, 21: 283-325.

Cinque, Guglielmo, and Luigi Rizzi. 2010. "The Cartography of Syntactic Structures." In The Oxford Handbook of Linguistic Analysis, edited by Bernd Heine and Heiko Narrog, 51-65. Oxford: Oxford University Press.

Foulet, Lucien. 1919. Petite syntaxe de l'ancien francais. Paris: Champion.

Foulet, Lucien. 1924. "L'accent tonique et l'ordre des mots: formes faibles du pronom personnel après le verbe.” Romania, 50: 54-93. 
Gerlach, Birgit. 1998. Restrictions on Clitic Sequences and Conditions on the Occurrence of Clitics in Romance. Düsseldorf: Heinrich Heine Universität Düsseldorf.

Grimshaw, Jane. 1997. "The Best Clitic: Constraint Interaction in Morphosyntax.” In Elements of Grammar: Handbook of Generative Syntax, edited by Liliane Haegeman, 169-196. Dordrecht: Kluwer.

Grimshaw, Jane. 2000. "Optimal Clitic Positions and the Lexicon in Romance Clitic Systems.” In Optimality Theoretic Syntax, edited by Géraldine Legendre, Jane Grimshaw, and Sten Vikner, 205-240. Cambridge, MA: MIT Press.

Halle, Morris, and James Harris. 2005. "Unexpected Plural Inflections in Spanish: Reduplication and Metathesis." Linguistic Inquiry, 36 (2): 195-222.

Halle, Morris, and Alec Marantz. 1993. "Distributed Morphology and the Pieces of Inflection." In The View from Building 20, edited by Kenneth Hale and Samuel Jay Keyser, 111-176.

Cambridge, MA: MIT Press.

Harris, James. 1994. "The Syntax-Phonology Mapping in Catalan and Spanish Clitics.” MIT Working Papers in Linguistics, 21: 321-353.

Harris, James. 1997. "Why n'ho is pronounced [lil in Barceloni Catalan." MIT Working Papers in Linguistics 30: 451-479.

Haspelmath, Martin. 2004. "Explaining the Ditransitive Person-Role Constraint: A Usage-Based Account." Constructions, 2: 1-49.

Heap, David. 1998. "Optimalizing Iberian Clitic Sequences.” In Theoretical Analyses on Romance Languages, edited by José Lema and Esthela Treviño, 227-248. Amsterdam: John Benjamins.

Jones, Michael Allan. 1993. Sardinian Syntax. London: Routledge.

Kayne, Richard. 1994. The Antisymmetry of Syntax. Cambridge, MA: MIT Press.

Kayne, Richard. 2000. Parameters and Universals. Oxford: Oxford University Press.

Kayne, Richard. 2008. "Expletives, datives, and the tension between morphology and syntax." In The Limits of Syntactic Variation, edited by Theresa Biberauer, 175-217. Amsterdam: John Benjamins.

Kayne, Richard. 2010. "Toward a Syntactic Reinterpretation of Harris and Halle (2005)." In Romance Languages and Linguistic Theory 2008: Selected Papers from 'Going Romance' Groningen 2008, edited by Reineke Bok-Bennema, Brigitte Kampers-Manhe, and Bart Hollebrandse, 145-170. Amsterdam: John Benjamins.

Laenzlinger, Christopher. 1993. "A Syntactic View of Romance Pronominal Sequences.” Probus, 5 (3): 242-270.

Laenzlinger, Christopher. 1994. "Enclitic Clustering: The Case of French Positive Imperatives." Rivista di Grammatica Generativa, 19: 71-104.

Manzini, Maria Rita. 2013. "From Romance Clitics to Case: Split Accusativity and the Person Case Constraint.” MS, University of Florence.

Manzini, Maria Rita, and Leonardo Savoia. 2002. "Clitics: Lexicalization Patterns of the So-Called 3rd Person Dative." Catalan Journal of Linguistics, 1: 117-155.

Manzini, Maria Rita, and Leonardo Savoia. 2004. "Clitics: Cooccurrence and Mutual Exclusion Patterns." In The Structure of CP and IP, edited by Luigi Rizzi, 211-250. New York, NY: Oxford University Press.

Manzini, Maria Rita, and Leonardo Savoia. 2005. I dialetti italiani e romanci: morfosintassi generativa. Alessandria: Edizioni Dell'Orso.

Manzini, Maria Rita, and Leonardo Savoia. 2009. "Morphology Dissolves into Syntax: Infixation and Doubling in Romance Languages." Annali Online di Ferrara: Lettere, 1: 1-28.

Meklenborg Salvesen, Christine. 2011. "Pronominal Reorganisation in Old and Middle French." MS, University of Oslo.

Melander, Johan. 1929. "L'origine de l'Italien me ne, me lo, te la, etc." Studia Neophilologica, 2: 169-203. 
Menn, Lise, and Brian MacWhinney. 1984. "The Repeated Morph Constraint.” Language, 60: 519541.

Nevins, Andrew. 2007. "The Representation of Third Person and Its Consequences for Person-Case Effects." Natural Language and Linguistic Theory, 25: 273-113.

Ormazabal, Javier, and Juan Romero. 2007. "The Object Agreement Constraint.” Natural Language and Linguistic Theory, 25 (2): 315-347.

Parry, Mair. 2005. Parluma 'D Còiri: sociolinguistica e grammatica del dialetto di Cairo Montenotte. Savona: Editrice Liguria.

Perlmutter, David. 1971. Deep and Surface Structure Constraints in Syntax. New York, NY: Holt, Rinehart and Winston.

Pescarini, Diego. 2010. "Elsewhere in Romance: Evidence from Clitic Clusters." Linguistic Inquiry, 41 (3): 427-444.

Pescarini, Diego. 2014. "The Evolution of Italo-Romance Clitic Clusters: Prosodic Restructuring and Morphological Opacity." In Diachrony and Dialects: Grammatical Change in the Dialects of Italy, edited by Paola Benincà , Adam Ledgeway, and Nigel Vincent, 155-176. New York, NY: Oxford University Press.

Poletto, Cecilia. 2000. The Higher Functional Field: Evidence from Northern Italian Dialects. New York, NY: Oxford University Press.

Postal, Paul M. 1990. "French Indirect Object Demotion." In Studies in Relational Grammar 3, edited by Paul M. Postal and Brian D. Joseph, 104-200. Chicago, IL: University of Chicago Press.

Radford, Andrew. 1977. "Counter-Filtering Rules." York Papers in Linguistics, 7: 7-45.

Rezac, Milan. 2008. "The Syntax of Eccentric Agreement: The Person Case Constraint and Absolutive Displacement in Basque." Natural Language and Linguistic Theory, 26: 61-106.

Rezac, Milan. 2010. "Ineffability Through Modularity: Gaps in the French Clitic Cluster." In Defective Paradigms: Missing Forms and What They Tell Us, edited by Matthew Baerman, Greville G. Corbett, and Dunstan Brown, 151-180. Oxford: Oxford University Press.

Rezac, Milan. 2011. Phi-Features and the Modular Architecture of Language. Dordrecht: Springer. Rizzi, Luigi. 1982. Issues in Italian Syntax. Dordrecht: Foris.

Rooryck, Johan. 1992. "Romance Enclitic Ordering and Universal Grammar." Linguistic Review, 9 (3): 219-250.

Săvescu Ciucivara, Oana. 2007. "Challenging the Person Case Constraint: Evidence from Romanian." In Romance Linguistics 2006: Selected Papers from the 36th Linguistic Symposium on Romance Languages, edited by José Camacho, Nydia Flores-Ferrán, Liliana Sánchez, et al., 255-269. Amsterdam: John Benjamins.

Somesfalean, Stanca. 2005. "On Two Issues Related to the Clitic Clusters in Romance Languages". In UG and External Systems: Language, Brain and Computation, edited by Anna Maria Di Sciullo, 27-53. Amsterdam: John Benjamins.

Tortora, Christina. 2002. "Romance Enclisis, Prepositions, and Aspect." Natural Language and Linguistic Theory, 20 (4): 725-757. 